\title{
VISUAL CULTURE IN THE NEW COMMUNICATION ENVIRONMENT: E-GOVERNMENT AS A CASE STUDY
}

\author{
Cengiz ERDAL \\ Yeditepe University, Visual Communication Design Department, İstanbul, Turkey \\ cengiz.erdal@gmail.com
}

\begin{abstract}
Emerging of internet and broadband connection enabling large amount of information to be transferred from one point to another have caused many services to be transferred to virtual environment causing face to face communication is being replaced by screen to screen communication. Consequently, individuals encounter more and more visuals than ever before, which develops and forms the visual culture through new ICT tools. One of the conspicuous applications that shapes visual culture is e-government system requiring effective HCI applications to be put into practice in adapting users to get used to visual interactions changing their deeply rooted transaction habits. This study aims to reveal evolving nature of visual culture in virtual environment as a result of new information communication technology devices serving us as intermediaries between traditional services that we are used to get through face to face communication and their virtual applications in cyberspace. Egovernment system is examined as a case study as it is an outstanding example of visual culture forming tool.
\end{abstract}

Keywords: ICT, Culture, e-Government, Visual.

\section{INTRODUCTION}

New communication tools have been changing our lives significantly. As Marshal McLuhan states, more we develop communication tools more they change our lives. Cyberspace, in which internet operates, has been facilitating the life for human beings causing to change the ways many things are done. Almost twenty years ago no one ever imagined that there would be an environment where interactive communication takes place through wireless devices enabling users being in touch with friends at all times, letting all friends know where we are through media tools, managing business without going to an office, doing almost all banking transactions from home, sending substantial amount of information within seconds from even one continent to another, reading all the newspapers without touching the papers, commending on the news while reading the news, seeing other readers' commends in the same place and being able to answer them, participating life programs on TVs from home letting them know about our opinions and using the same device, taking a photograph, adding a text message and then sending it to another person in seconds. They have realized as a result of the developments in communication.

Cyberspace, in which the internet operates requires us to coincide visuals more than ever before in the history. Therefore, using, interpreting and constructing meaning out of visuals have become an important part of our lives. As a new visual communication environment encountering many visual images, e-government system is one of the most conspicuous venues where we need visual literacy the most, through which visual culture is shaped.

\section{CULTURE, DIGITALIZATION AND VISUAL CULTURE}

As individuals we are living in a world where culture plays a crucial role. Culture emerges and forms itself over the years among human beings. Even we do not realize it and not being able to see it physically around us, as it is everywhere we are surrounded by the culture. There is a kind of interaction between the tools that humans create to facilitate their lives and the culture itself. More the tools are used by individuals, more they change and/or evolve the human beings' lives and their culture accordingly. Being such an important fact of life, over the years meaning of culture has changed dramatically. Williams states that, after the nineteenth century culture as a word has earned certain meanings: First, the general condition 
of the mind, having distinguished relations of human perfection as an idea. Second, it came to mean, intellectual development in a society in general. Third, it meant general body of the arts. Finally, as fourth, it came to mean, general way of life, intellectual and material. Emergence of culture compounds two main responses: First, respecting the practical differences between certain intellectual as well as moral activities and the domination power of a new sort of society. Second, the importance of these activities, as a mean of human desire setting over the phases of social and practical judgment offering itself as a diminishing and rallying choices. In the historical development, above mentioned compounded two main responses have integrated in themselves and changed by the growing assertion of a general way of life as a mode inferring all our common experience and through which transforming it. Emergence of culture is also involved in new sort of social and personal relationship and also a response to the new socio-political developments, in other words to Democracy. (Williams, 1960). In that sense it can be said that culture is a response to internet environment as it is thought to be a socio-politic or democratic environment, may be the most democratic environment ever created in the history in terms of representation and pluralism that it offers to minorities and to those who have not had many chances to be heard in the societies. Besides, it provides humans with more participative environments.

Developments realized in ICT (information communication technology), shored up with fiber cable, wireless connection and $3 \mathrm{G}$ mobile connections have conduced aforementioned facilities to be brought about. Moreover, almost all kinds of goods, services and information can be reached and bought over the internet even when we are on the move, without being face to face with another person. As a result, ICT devices especially mobile ones have been penetrating into our lives with an incredible velocity, in which visual images also move from one user to another with the same speed. More ICT is used and become an indispensable part of our lives more visual contents and visual images are created and used by ICT users. The reason for this being is after the internet entered our lives, especially individual journalism where we are able to publish whatever we like such as daily developments of our lives and/or what we find interesting and worth to share with our network and also with the rest of the world without needing a publisher and the most importantly not having to be subjected to gatekeeping - and using social media tools in order to express ourselves and our ideas became a new and prevalent way of life. Especially, emergence of digital photography has been the foundation of the radical change and development in communcaiton. All those new venues have conduced producing and sharing of digital visual contents of daily experiences amongst internet users to become so easy with the help of mobile multimedia devices, through which we are able to produce various contents and connect to the internet at all times. Aforementioned new environments have been imposing new cultures in our lives evolving the existing communication culture.

Ever since those changes in communication emerged, we have been increasingly living in a life that is based on visuality, in which visual culture has been developing and evolving through various digital applications and their convergence in the media. Digitalization of visual media contents makes it easy to share cultural products amongst individuals through new communication environments. Concept of convergence in media provides new and integrated ways of submitting media contents to media consumers, which shores up and enhances visual digital culture. All those aforementioned developments, new applications and structures that lead to cultural change in communication have conduced emphasis to turn to visual culture. One of the latest applications in cyberspace that constitute visual culture is egovernment, where governments and their citizens interact each other.

\section{E-GOVERNMENT AS VISUAL CULTURE}

We all encounter many visual images during the day consequence of prevalent usage of internet. One of the virtual services, through which we coincide many virtual images, in cyberspace is e-government system. As a result of electronic versions of the services, it is not 
necessary for us to go to the government buildings for most of the services. E-government system brings about radical changes just like other electronic services. E-government system is a communication system itself, which is possible to benefit through ICT devices. The virtual interactive services provide governments with a great chance of renewing and vitalizing relationship with their citizens through screen to screen communication. It should not be overlooked that those interactions take place in a virtual environment where face to face communication is no longer exist. So, HCI (human communication interaction) involves in cyber-communication environment through which meaning construction is done mostly through visual images and visual representations unlike face to face communication. Human computer interaction concerns with assessment, putting into operation and design. It tries to ensure usability, appeal, efficiency, effectiveness and safety. More those components are considered in cyber-communication, more it will be easy and successful the communication will be in virtual environment, which will help to progress visual literacy among users.

As visuality is the primary element of cyber communication, their various usages are the case in this communication environment that leads us to visual literacy. That is a concept plays an intermediary role in constitution of visual culture. Visual literacy is all about the ability of understand and use images, which comprises two main skills: First is the awareness of the attitudes and feelings conveyed in visual messages. Second is the ability to produce meaningful images in communication with others. All those elements conduce to constitute visual culture. Mirzoeff argues that visual culture has become conspicuous as a result of many critics scholars and artists have thought that prevalence of visual can not be completely explained through existing visual disciplines (Mirzoeff, 2002). Therefore, evolution of visual culture needs to be well understood and to be paid attention in order to convey the message we want to get across effectively in cyber-communication. In the new computerized communication environment where digitalization is the main concept, visualization has gained a new aspect through digital content creation, which caused to spring up new media product such as digital films, video games and simulation based contents constituting the term digital visual culture.

Mirzoeff states that the main essence of visual culture's practice is the visual event, which is the realization of a network where subjects operate respecting each other's freedom of action (Mirzoeff,2002). As it is a large communication network system, e-government system itself comprises many multi-visual events. All those multi-visual events constitute visual culture of governance for both users in benefiting from digital visual services and for governments in serving their citizens through visual communication, which used to be face to face communication when traditional services were the case. In the new venue of e-government system, citizens communicate with the governments through visual events, which are created by intermediation of interfaces, such as going through visual contents and images to reach certain information, filling out forms, submitting petitions, filing a return and so on. All those events require and also develop visual literacy that comprises certain abilities to understand and to use images. All those phases are realized through HCI where the visual perception of users takes place.

It should always be considered that visual perception plays a crucial role in the meaning creation process of visual events, through which visual culture is constituted. In the process of visual perception, visual information comes from our senses then, our brain perceives and stores the information. Perception comprises interacting of information that sent from senses with our prior knowledge stored in the memory. In this process of visualizing information our brains tries to match known patterns, which is necessary for object perception. Once our brain recognizes an object, it is much easier to recognize the same object on a following encounter anywhere in the visual field (Hoober and Berkman,2011). There are some important characteristics of perception: It is selective, so we do not pay attention to everything we encounter during the day. It is immediate that we whether use and store the stimulus 
straightaway or not. It is stable in terms of our senses and also it is meaningful for us so, we get something out of it.

\section{CONCLUSION}

Ever since cyberspace has started to be used as a new communication environment, usage of visual images has come forward much more than any other way of meaning construction in that environment. There are certain reasons of virtual environment's widespread usage, such as digitalization of media contents and products, being able to provide opportunity to realize individual journalism through multimedia devices, providing chance to contact with the friends staying online at all times, being the most democratic communication environment having the opportunity to express our feelings and thoughts. In spite of all the advantages, it should be considered that it is a different communication environment than others. Therefore, it is subject to certain rules to be followed in order to be successful in transferring the message. The new communication environment is the place where HCI takes place, which requires effective use of visuals as to be able to communicate effectively. Consequently, visual literacy plays a critical role in cyber-communication.

E-government is one of the virtual communication environments, where government services are served to citizens, operating in cyberspace as a new way of communication between governments and citizens. As a result of many visual applications and digital visual services, through which virtual communication is established, e-government system of visual governance serving as a subculture is an important environment in creation of visual culture itself. It is blatant that all aforementioned developments including e-government system, in which widespread usage of visuality through digital content creation in new communication environments, have been constituting visual culture.

\section{REFERENCES}

[1] Albrow, M., King, E.(1990).Globalization, Knowledge and Society. London: SAGE Publications.

[2] Armitage, J., Roberts, J.(2002). Living With Cyberspace, London: Continuum.

[3] Arslan, M., Akıncı, S. K., Karapınar, P. B.(2007). E-İş, E-Devlet, Etik. Ankara: Siyasal Kitabevi.

[4] Aydoğan, F., Akyüz, A..(2010). İkinci Medya Çağında Ínternet. İstanbul: Alfa Basım Yayın [1] Dağıtım San. Ve Tic. Ltd. Şti.

[5] Barney, D.(2007). The Network Society. Cambridge: Polity Press.

[6] Barry, A. M. S.(1997).Visual Intelligence, Albany: State University of New York Press.

[7] Castells, M.(1998). The Rise Of The Network Society. Massachusetts: Blackwell

Publishers.

[8] Castells, M.(1998). End of Millennium. Massachusetts: Blackwell Publishers.

[9] Currie, W. (1995). Management Strategy for I.T. London: Financial Times Management.

[10] Devlet Planlama Teşkilatı Bilgi Toplumu Dairesi.(2005). E-Devlet Proje ve

Uygulamaları. Ankara: Devlet Planlama Teşkilatı Yayınevi.

[11] Dominick, J. R.(2005). The Dynamics of Mass Communications. NY: The McGraw-

Hill Companies.

[12] Evans, J., Hall, S.(2002). Visual Culture: The Reader. London: Sage Publications.

[13] Heeks, R.(2007). E-Government measurement and evaluation. Available at:

http://www.oecd.org/dataoecd/45/20/38404067.ppt\#273,7,eGovernment Measurement and

Evaluation: Objectives and Challenges.

[14] Hoober, S., Berkman, E.(2011). Designing Mobile Interfaces, Beijing: O'reilly.

[15] Frissen, P. H. A.(1999). Politics, Governance and Technology. Massachusetts: Edward Elgar Publishing Ltd.

[16]Jones, S., Sharif, Z.(2007). E-Government evaluation. Available at: http://www.epractice.eu/en/library/281660 
[17] Kuran, N. H.(2005). Türkiye İçin E-Devlet Modeli. İstanbul: İstanbul Bilgi Üniversitesi Yayınları.

[18] Lester, P. M.(2003). Visual Communication. Belmont: Wadsworth/Thomson Learning. [19] Messaris, P.(1997). Visual Persuasion. Thousand Oaks: SAGE Publications.

[20] Mirzoeff N.(2003). An Introduction to Visual Culture. London: Routledge.

[21] Mirzoeff N.(2002).The Visual Culture Reader, London: Routledge.

[22] Strate, L., Jacobson, R. L., Gibson, S.(2003).Communication and Cyberspace, NJ: Hampton Press.

[23] Tufte, R. R.(1997). Visual Explanations. Connecticut: Graphics Press.

[24] Türkoğlu, T.(2010). Dijital Kültü̈r., İstanbul : Bayaz Yayınları.

[25] Odabaş, H.(2009). E-Devlet Sürecinde Elektronik Belge Yönetimi. İstanbul: Hiperlink Yayınları.

[26] Oskamp, S., Schultz, P. W.(2005). Attitudes and Opinions. New Jersey: Lawrence Erlbaum Associates, Inc., Publishers.

[27] Warschauer, M.(2003). Technology and Social Inclusion, Cambridge:.The MIT Press. [28] Webster, F.(2006). The Information Society Reader. NY: Routledge.

[29] Wiberg, M.(2005). The Interaction Society. Hershey: Information Society Publishing.

[30] Williams, R.(1960). Culture \& Society: 1780-1950. NY: Anchor Books.

[31] Winston, B.(2003). Media Technology and Society, London: Routledge.

[32] Wood, A. F., Smith, M.(2005). Online Communication. NY: Routledge. 